Cvijanović, D., Stanišić, T., Leković, M., Kostić, M. (2020): Indicators of agricultural and rural development in the East Central and South-East European countries. Agriculture and Forestry, 66 (2): 19-32

DOI: 10.17707/AgricultForest.66.2.02

\begin{abstract}
Drago CVIJANOVIĆ, Tanja STANIŠIĆ, Miljan LEKOVIĆ and Marija KOSTIĆ ${ }^{1}$
\end{abstract}

\title{
INDICATORS OF AGRICULTURAL AND RURAL DEVELOPMENT IN THE EAST CENTRAL AND SOUTH-EAST EUROPEAN COUNTRIES
}

\section{SUMMARY}

Rural development is largely determined by the available resources and competitiveness of agriculture. The results achieved in agriculture are a significant factor that affects the improvement of the life quality in rural areas and the efficiency of the rural economy. Hence the indicators of agriculture and rural development are common and inseparable. The main purpose of the paper is systemic analysis of indicators of agriculture and rural development in the East Central and South-East European countries. The heterogeneous structure of the analysed group of countries enables their further division into the European Union (EU) Member States and non-EU countries and consideration of differences in the results achieved in these two subgroups. The methods applied in the paper are descriptive statistics, analysis of variance, cluster analysis and correlation analysis. The results of the research enable evaluation of the relative position of the countries according to the analysed indicators, identification of the countries with relatively better performance, but also the direction and intensity of the link between selected indicators of agricultural and rural development in the analysed group of countries.

Keywords: agriculture; rural development; results; indicators.

\section{INTRODUCTION}

Rural areas have a great natural, demographic, economic and cultural potential (Despotović et al., 2017; Dimitrovski et al., 2019; Filipović, 2018), so the rational utilization of that wealth can potentially provide diversified development, full employment, and high living standards and quality of life for the rural population (Erokhin et al., 2014; Podovac et al., 2019). Nevertheless, most of the world's poorest people live in rural areas and this situation is not expected to change for some years. In the past few decades rural areas have experienced major economic and social changes: agriculture and forestry

\footnotetext{
${ }^{1}$ Miljan Leković (corresponding author: m.lekovic@kg.ac.rs), Drago Cvijanović, Tanja Stanišić, Marija Kostić, University of Kragujevac, Faculty of Hotel Management and Tourism in Vrnjačka Banja, SERBIA

Paper presented at the GEA (Geo Eco-Eco Agro) International Conference 2020, Podgorica.

Notes: The authors declare that they have no conflicts of interest. Authorship Form signed online.

Received:15/04/2020

Accepted:02/06/2020
} 
(traditionally strong primary industries) have decreased dramatically in many countries (Saarinen, 2007). But still, 77\% of the area of the EU member countries are dominated by agriculture and forestry (Piorr, 2003).

The production system such as agriculture is crucially dependent on the environment and impact on it. The environmental impact of agriculture is directly dependent on the land use (Spalevic et al., 2017a), and the land use also reflects the development trends of agriculture and the overall vitality of rural areas (YliViikari et al., 2002). At the same time rural areas are often economically backward (Trišić, 2019), so economic revitalization of rural areas is a priority of national development (Mickovic et al., 2020; Spalević et al., 2017b; Zekić et al., 2017). For this reason, sustainability of rural areas in general terms means the retention of rural inhabitants in their traditional environment by means of the provision of sustainable employment and income (Kiseleva et al., 2013).

In the context of the efforts of countries in modern conditions to define and implement an adequate rural development strategy and ensure the well-being of the rural population, it is important to monitor indicators and measure the achieved level of rural development. Agriculture, which provides socio-economic development of rural areas, plays important role in this process (Despotović et al., 2016; Katić et al., 2011, Gajić et al., 2017). Many indicators and variables are used for examining the agricultural and rural development level in a particular community or country. Indicators are an area of growing interest. They help to transform the raw data into a form that facilitates the decision-making and the managing the complex issues such is rural development. The UN Commission on Sustainable Development (CSD), European Centre for Nature Conservation (ECNC), World Bank, Food and Agriculture Organization (FAO) and several single nations have contributed to development of the agri-environmental and rural indicators (Bryden 2001; Bryden et al., 2000; FAO, 1998; Ilić et al., 2017; MAFF, 2000; McRae et al., 2000; Wascher, 2000; World Bank, 2000; WWF, 2000). There are several studies that are based on the analyses with some of these indicators. The study of Pierangeli et al. (2008) describes the functions of rural development for the EU-25 using indicators and their results show the difference between Southern and Northern European countries. Research of Hossain et al. (2015) shows the significance of rural development multidimensionality, actually an integrated approach when choosing variables. Ciutacu et al. (2015) show the difference in agriculture development between Western and Eastern European countries, where agricultural production was structured on the principles of collective ownership. Agricultural and rural development indicators prescribed by the World Bank are the subject of analysis in this paper.

The main focus of the paper is on the analysis of selected indicators of agricultural and rural development in the East Central and South-East European countries. The group of the East Central and South-East European countries consists of countries that differ not only in economic strength and potential for agricultural and rural development, but also from countries with different policies and strategies of this development. Some of them have recently redefined their 
attitude towards agriculture and rural development and understand their importance in modern conditions. In others, rural development is still overshadowed by agricultural development. There are countries in this group in which agriculture is one of the most important economic activities or the population is predominantly rural. Some of the countries, not all, are members of the EU. All above mentioned allows the analysis of indicators of agricultural and rural development of the East Central and South-East European countries in order to draw conclusions about the results of the group as a whole, but also to identify subgroups and individual countries that achieve relatively better performance.

The results of the research are divided into several segments. Primarily, a cross-country comparison of selected indicators in the analysed group of countries is presented, within which the minimum, maximum and mean values are also determined, as well as the variability of indicator values by subgroups of countries (EU and non-EU countries) within the analysed group. After that, the countries are classified into two clusters according to the achieved performance in agricultural and rural development. Finally, the direction of the relationship between the selected indicators in the East Central and South-East European countries is examined. This structuring of research results is in the function of realizing the defined goals of the research, i.e., comparing the performance of subgroups of countries, examining the homogeneity of countries according to the analysed indicators within the defined subgroups and examining the interdependence of analysed indicators.

In accordance with the defined research objectives, the following initial hypotheses are tested: a) East Central and South-East European countries that are not members of the EU record relatively better results (relative values of agricultural and rural development indicators) compared to a subgroup of EU countries; b) there is homogeneity of countries according to the analysed indicators within the defined subgroups of East Central and South-East European countries (EU and non-EU countries) and c) there is a statistically significant relationship between the analysed indicators of agricultural and rural development in East Central and South-East European countries.

\section{MATERIAL AND METHODS}

The information basis of the research represent indicators of agricultural and rural development of the World Bank. In order to ensure comparability of data, indicators given in relative values, i.e., indices, are selected. Also, in order to uniformise the data, the data from 2016 are analysed, since this is the last year in which data on all selected indicators are available. The following indicators are included in the analysis: "Agricultural land (\% of land area), Arable land (\% of land area), Forest area (\% of land area), Agriculture, forestry, and fishing, value added $(\%$ of GDP), Food production index $(2004-2006=100)$, Livestock production index $(2004-2006=100)$, Crop production index $(2004-2006=100)$, Rural population ( $\%$ of total population), Employment in agriculture (\% of total 
employment), Employment in agriculture, female (\% of female employment) and Employment in agriculture, male (\% of male employment)“ (World Bank, 2020).

The data for the group of East Central and South-East Europe Countries, according to the classification of the United Nations Group of Experts on Geographical Names (UNGEGN) are analysed in the paper. According to this classification, group of the East Central and South-East Europe Division Countries includes the following countries: Albania, Bosnia and Herzegovina, Bulgaria, Croatia, Cyprus, Czech Republic, Georgia, Greece, Hungary, Montenegro, North Macedonia, Poland, Romania, Serbia, Slovakia, Slovenia and Ukraine (UNGEGN, 2020). The heterogeneous group of countries enabled their further division into two subgroups: EU countries and non-EU countries, which is used in certain segments of the analysis. The methods applied in the paper are: descriptive statistics, analysis of variance, cluster analysis and correlation analysis. Descriptive statistics are used to answer the question of whether better relative results are recorded in the subgroup of the non-EU countries compared to the subgroup of the EU countries. Analysis of variance is used to examine the significance of the difference in the analysed indicators between the defined subgroups of countries. The homogeneity of countries within the defined subgroups according to indicators of agricultural and rural development is examined using cluster analysis. Correlation analysis is used to examine the interdependence of selected indicators of agricultural and rural development in the East Central and South-East Europe Countries.

\section{RESULTS AND DISCUSSION}

The results of the research are divided into three segments:

1. Cross-country comparison,

2. Examination of homogeneity of countries within defined subgroups according to indicators of agricultural and rural development, and

3. Examination of the interdependence of agricultural and rural development indicators in the East Central and South-East Europe Countries.

\section{Cross-country comparison}

Selected indicators of agricultural and rural development in the East Central and South-East European countries are shown in Table 1. For the purpose of further analysis, the results for the subgroup of EU countries and the subgroup of non-EU countries are presented separately.

When it comes to "Agricultural land (\% of land area)", the highest percentage share is recorded in Ukraine, followed by Romania, Hungary and Northern Macedonia as countries where more than half of the land area is agricultural land. Montenegro and Cyprus are the countries with the lowest relative value of this indicator.

According to "Arable land (\% of land area)", in addition to Ukraine, countries with a high percentage share are Hungary, Poland and Romania, while the lowest are recorded in Montenegro, Cyprus and Slovenia. 
Table 1. Selected indicators of agricultural and rural development in the East Central and South-East European countries

\begin{tabular}{|c|c|c|c|c|c|c|c|c|c|c|c|}
\hline & 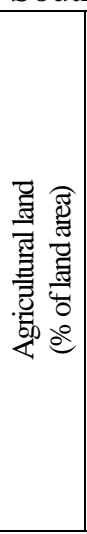 & 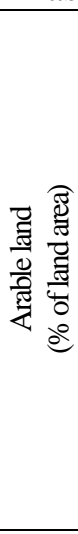 & 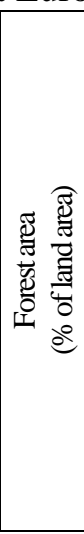 & 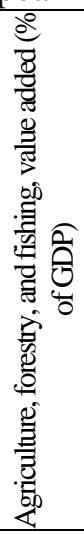 & 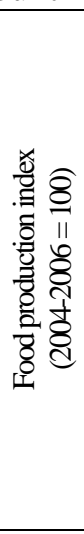 & 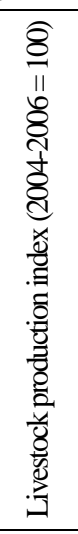 & 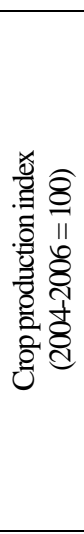 & 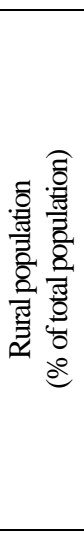 & 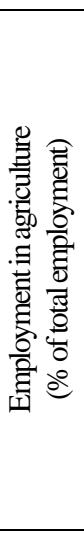 & 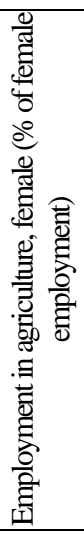 & 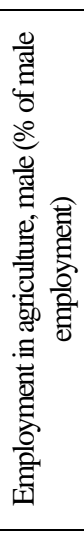 \\
\hline \multicolumn{12}{|c|}{ EU countries } \\
\hline Bulgaria & 46.25 & 32.20 & 35.37 & 4.05 & 129.9 & 84.39 & 128.1 & 25.67 & 6.75 & 4.25 & 8.94 \\
\hline Croatia & 27.59 & 15.58 & 34.35 & 3.14 & 128.2 & 94.02 & 133.2 & 43.59 & 7.60 & 5.55 & 9.35 \\
\hline Cyprus & 12.16 & 9.16 & 18.69 & 3.14 & 79.14 & 88.86 & 64.25 & 33.12 & 3.64 & 1.64 & 5.35 \\
\hline Czech Republic & 45.18 & 32.30 & 34.56 & 2.21 & 102.5 & 87.62 & 115.2 & 26.43 & 2.90 & 1.72 & 3.83 \\
\hline Greece & 47.60 & 16.60 & 31.69 & 3.46 & 95.1 & 91.91 & 92.9 & 21.61 & 12.37 & 11.75 & 12.82 \\
\hline Hungary & 58.36 & 47.76 & 22.91 & 3.72 & 87.2 & 81.9 & 90.45 & 29.22 & 5.04 & 2.84 & 6.89 \\
\hline Poland & 46.94 & 35.29 & 30.88 & 2.38 & 117.6 & 109.9 & 118.6 & 39.82 & 10.58 & 9.39 & 11.55 \\
\hline Romania & 58.77 & 37.30 & 30.12 & 4.06 & 112.9 & 84.73 & 101.3 & 46.10 & 23.10 & 22.62 & 23.47 \\
\hline $\begin{array}{c}\text { Slovak } \\
\text { Republic }\end{array}$ & 39.23 & 28.02 & 40.35 & 3.32 & 101.8 & 76.9 & 118.8 & 46.19 & 2.89 & 1.41 & 4.09 \\
\hline Slovenia & 30.66 & 9.13 & 61.97 & 1.88 & 88.7 & 89.62 & 86.33 & 45.98 & 5.02 & 4.16 & 5.76 \\
\hline \multicolumn{12}{|c|}{ non-EU countries } \\
\hline Albania & 43.13 & 2.64 & 28.12 & 19.91 & 150.9 & 113.1 & 82.1 & 41.58 & 9.76 & 45.16 & 35.89 \\
\hline $\begin{array}{c}\text { Bosnia and } \\
\text { Herzegovina }\end{array}$ & 43.14 & 20.04 & 42.68 & 6.37 & 125.4 & 119.7 & 118.3 & 52.48 & 17.96 & 17.77 & 18.07 \\
\hline Georgia & 34.45 & 4.95 & 40.62 & 7.73 & 71.48 & 69.22 & 77.54 & 42.16 & 43.81 & 45.65 & 42.18 \\
\hline Montenegro & 18.96 & 0.67 & 61.49 & 7.47 & 63.25 & 71.44 & 54.13 & 33.86 & 7.74 & 7.40 & 8.02 \\
\hline $\begin{array}{c}\text { North } \\
\text { Macedonia }\end{array}$ & 50.16 & 16.49 & 39.57 & 9.17 & 125.3 & 113 & 124.4 & 42.44 & 16.63 & 15.76 & 17.19 \\
\hline Serbia & 39.33 & 29.71 & 31.12 & 6.49 & 98.59 & 100.9 & 106.5 & 44.19 & 18.61 & 16.17 & 20.52 \\
\hline Ukraine & 71.67 & 56.58 & 16.71 & 11.73 & 169.1 & 97.46 & 192.2 & 30.85 & 15.6 & 13.17 & 17.85 \\
\hline
\end{tabular}

Source: World Bank (2020)

In contrast, "Forest area (\% of land area)" is most represented in Slovenia and Montenegro, and least in Ukraine. When it comes to one of the analysed macroeconomic indicators of agricultural development, "Agriculture, forestry, and fishing, value added (\% of GDP)", Albania is the country with the highest share, while Slovenia is the country with the lowest share. Ukraine and Albania are the countries with the highest value of the food production index and crop production index in relation to the selected base period, while Montenegro records the lowest values of these indices. When it comes to the livestock 
production index, the highest base index is recorded in Bosnia and Herzegovina, and the lowest in Georgia. Bosnia and Herzegovina is also the country with the highest share of rural population in the total, while this share is the lowest in Greece. Georgia stands out as the country with the largest share of employment in agriculture (total, female and male), while the Slovak Republic, the Czech Republic and Cyprus can stand out as the countries with the lowest percentages of these indicators.

Table 2. Descriptive statistics

\begin{tabular}{|c|c|c|c|c|c|c|}
\hline Indicators & Countries & Minimum & Maximum & Mean & $\begin{array}{c}\text { Std. } \\
\text { Deviation }\end{array}$ & $\begin{array}{c}\text { Variation } \\
\text { Coefficient }\end{array}$ \\
\hline \multirow{2}{*}{$\begin{array}{l}\text { Agricultural land } \\
\text { (\% of land area) }\end{array}$} & EU countries & 12.16 & 58.77 & 41.27 & 14.38322 & 0.35 \\
\hline & $\begin{array}{l}\text { non-EU } \\
\text { countries }\end{array}$ & 18.96 & 71.67 & 42.98 & 16.00917 & 0.37 \\
\hline \multirow{2}{*}{$\begin{array}{c}\text { Arable land } \\
\text { (\% of land area) }\end{array}$} & EU countries & 9.13 & 47.76 & 26.33 & 13.05418 & 0.50 \\
\hline & $\begin{array}{l}\text { non-EU } \\
\text { countries }\end{array}$ & 0.67 & 56.58 & 21.58 & 18.41324 & 0.85 \\
\hline \multirow{2}{*}{$\begin{array}{c}\text { Forest area } \\
(\% \text { of land area) }\end{array}$} & EU countries & 18.69 & 61.97 & 34.09 & 11.60645 & 0.34 \\
\hline & $\begin{array}{l}\text { non-EU } \\
\text { countries }\end{array}$ & 16.71 & 61.49 & $\mid 37.19$ & 14.00357 & 0.38 \\
\hline \multirow{2}{*}{$\begin{array}{c}\text { Agriculture, forestry, and } \\
\text { fishing, value added } \\
\text { (\% of GDP) }\end{array}$} & EU countries & 1.88 & 4.06 & 3.14 & 0.75833 & 0.24 \\
\hline & $\begin{array}{l}\text { non-EU } \\
\text { countries }\end{array}$ & 6.37 & 19.91 & 9.84 & 4.80899 & 0.49 \\
\hline \multirow{2}{*}{$\begin{array}{l}\text { Food production index } \\
\quad(2004-2006=100)\end{array}$} & EU countries & 79.14 & 129.90 & 104.30 & 17.44944 & 0.17 \\
\hline & $\begin{array}{l}\text { non-EU } \\
\text { countries }\end{array}$ & 63.25 & 169.10 & 114.86 & 39.30876 & 0.34 \\
\hline \multirow{2}{*}{$\begin{array}{c}\text { Livestock production } \\
\text { index }(2004-2006=100)\end{array}$} & EU countries & 76.90 & 109.90 & 88.99 & 8.87625 & 0.10 \\
\hline & $\begin{array}{l}\text { non-EU } \\
\text { countries }\end{array}$ & 69.22 & 119.70 & 97.83 & 20.27365 & 0.21 \\
\hline \multirow{2}{*}{$\begin{array}{l}\text { Crop production index } \\
(2004-2006=100)\end{array}$} & EU countries & 64.25 & 133.20 & 104.91 & 21.57454 & 0.21 \\
\hline & $\begin{array}{c}\text { non-EU } \\
\text { countries }\end{array}$ & 54.13 & 192.20 & 122.17 & 50.63362 & 0.41 \\
\hline \multirow{2}{*}{$\begin{array}{c}\text { Rural population } \\
\text { (\% of total population) }\end{array}$} & EU countries & 21.61 & 46.19 & 35.77 & 9.64227 & 0.27 \\
\hline & $\begin{array}{c}\text { non-EU } \\
\text { countries }\end{array}$ & 30.85 & 52.48 & 41.08 & 7.06729 & 0.17 \\
\hline \multirow{2}{*}{\begin{tabular}{|c|} 
Employment in \\
agriculture \\
$(\%$ of total employment $)$
\end{tabular}} & EU countries & 2.89 & 23.10 & 7.99 & 6.18473 & 0.77 \\
\hline & $\begin{array}{c}\text { non-EU } \\
\text { countries }\end{array}$ & 7.74 & 43.81 & 22.87 & 13.45808 & 0.59 \\
\hline \multirow{2}{*}{\begin{tabular}{|c|} 
Employment in \\
agriculture, female (\% of \\
female employment)
\end{tabular}} & EU countries & 1.41 & 22.62 & 6.53 & 6.60783 & 1.01 \\
\hline & $\begin{array}{c}\text { non-EU } \\
\text { countries }\end{array}$ & 7.40 & 45.65 & 23.01 & 15.65511 & 0.68 \\
\hline \multirow{2}{*}{\begin{tabular}{|c|} 
Employment in \\
agriculture, male (\% of \\
male employment)
\end{tabular}} & EU countries & 3.83 & 23.47 & 9.21 & 5.86222 & 0.64 \\
\hline & $\begin{array}{c}\text { non-EU } \\
\text { countries }\end{array}$ & 8.02 & 42.18 & 22.82 & 11.89485 & 0.52 \\
\hline
\end{tabular}

Source: Authors' calculation (SPSS Statistics 23) 
Descriptive statistics of the analysed indicators are shown in Table 2. For comparison, the results of descriptive statistics are presented separately for the EU and non-EU countries.

Table 3. Results of One-way ANOVA

\begin{tabular}{|c|c|c|c|c|c|c|}
\hline & & $\begin{array}{l}\text { Sum of } \\
\text { Squares }\end{array}$ & $\mathrm{df}$ & $\begin{array}{l}\text { Mean } \\
\text { Square }\end{array}$ & $\mathrm{F}$ & Sig. \\
\hline \multirow{3}{*}{$\begin{array}{l}\text { (\% of land area) } \\
\text { Agricultural land }\end{array}$} & Between Groups & 11.944 & 1 & 11.944 & 0.053 & 0.822 \\
\hline & Within Groups & 3399.653 & 15 & 226.644 & & \\
\hline & Total & 3411.597 & 16 & & & \\
\hline \multirow{3}{*}{$\begin{array}{c}\text { Arable land } \\
\text { (\% of land area) }\end{array}$} & Between Groups & 92.949 & 1 & 92.949 & 0.391 & 0.541 \\
\hline & Within Groups & 3567.991 & 15 & 237.866 & & \\
\hline & Total & 3660.940 & 16 & & & \\
\hline \multirow{3}{*}{$\begin{array}{l}\text { Forest area } \\
\text { (\% of land area) }\end{array}$} & Between Groups & 39.523 & 1 & 39.523 & 0.248 & 0.626 \\
\hline & Within Groups & 2388.986 & 15 & 159.266 & & \\
\hline & Total & 2428.509 & 16 & & & \\
\hline \multirow{3}{*}{$\begin{array}{l}\text { Agriculture, forestry, and } \\
\text { fishing, value added } \\
\text { (\% of GDP) }\end{array}$} & Between Groups & 184.983 & 1 & 184.983 & 19.278 & 0.001 \\
\hline & Within Groups & 143.934 & 15 & 9.596 & & \\
\hline & Total & 328.917 & 16 & & & \\
\hline \multirow{3}{*}{$\begin{array}{l}\text { Food production index } \\
(2004-2006=100)\end{array}$} & Between Groups & 458.826 & 1 & 458.826 & 0.573 & 0.461 \\
\hline & Within Groups & 12011.419 & 15 & 800.761 & & \\
\hline & Total & 12470.245 & 16 & & & \\
\hline \multirow{3}{*}{$\begin{array}{c}\text { Livestock production } \\
\text { index }(2004-2006=100)\end{array}$} & Between Groups & 322.244 & 1 & 322.244 & 1.522 & 0.236 \\
\hline & Within Groups & 3175.214 & 15 & 211.681 & & \\
\hline & Total & 3497.459 & 16 & & & \\
\hline \multirow{3}{*}{$\begin{array}{l}\text { Crop production index } \\
(2004-2006=100)\end{array}$} & Between Groups & 1225.846 & 1 & 1225.846 & 0.940 & 0.348 \\
\hline & Within Groups & 19571.731 & 15 & 1304.782 & & \\
\hline & Total & 20797.577 & 16 & & & \\
\hline \multirow{3}{*}{$\begin{array}{c}\text { Rural population } \\
\text { (\% of total population) }\end{array}$} & Between Groups & 115.970 & 1 & 115.970 & 1.531 & 0.235 \\
\hline & Within Groups & 1136.440 & 15 & 75.763 & & \\
\hline & Total & 1252.410 & 16 & & & \\
\hline \multirow{3}{*}{$\begin{array}{l}\text { Employment in agriculture } \\
\text { (\% of total employment) }\end{array}$} & Between Groups & 912.179 & 1 & 912.179 & 9.562 & 0.007 \\
\hline & Within Groups & 1430.977 & 15 & 95.398 & & \\
\hline & Total & 2343.156 & 16 & & & \\
\hline \multirow{3}{*}{$\begin{array}{c}\text { Employment in } \\
\text { agriculture, female (\% of } \\
\text { female employment) }\end{array}$} & Between Groups & 1118.100 & 1 & 1118.100 & 9.000 & 0.009 \\
\hline & Within Groups & 1863.466 & 15 & 124.231 & & \\
\hline & Total & 2981.566 & 16 & & & \\
\hline \multirow{3}{*}{$\begin{array}{c}\text { Employment in } \\
\text { agriculture, male (\% of } \\
\text { male employment) }\end{array}$} & Between Groups & 762.961 & 1 & 762.961 & 9.881 & 0.007 \\
\hline & Within Groups & 1158.216 & 15 & 77.214 & & \\
\hline & Total & 1921.176 & 16 & & & \\
\hline
\end{tabular}

Source: Authors' calculation (SPSS Statistics 23)

The minimum values of six of total eleven analysed indicators are recorded in the East Central and South-East Europe Countries that are members of the EU (minimum percentage share of agricultural land, value added as a percentage of GDP, share of rural population and all types of employment). On the other hand, 
the maximum values of almost all analysed indicators (except the share of forest area in land area) are recorded in the East Central and South-East Europe Countries that are not members of the EU. Also, the mean values of almost all analysed indicators (except the share of arable land in the land area) are higher in the subgroup of non-EU countries. There is slightly higher variability between countries within the subgroup of non-EU countries according to seven of the eleven observed indicators (higher variability within the subgroup of EU countries is recorded only in the participation of the rural population in total and participation of all types of employment (total, female and male) in total employment.

Difference in mean values of the analysed indicators between defined subgroups of countries is tested by using analysis of variance (One-way ANOVA). The results are shown in Table 3.

The results presented in Table 3 show that the defined subgroups of the East Central and South-East Europe Countries (EU and non-EU countries) differ significantly according to "Agriculture, forestry, and fishing, value added (\% of GDP)", "Employment in agriculture (\% of total employment)", "Employment in agriculture, female (\% of female employment)" and "Employment in agriculture, male ( $\%$ of male employment)". On the other hand, variations in other analysed indicators between defined subgroups of countries are not statistically significant.

Examination of homogeneity of countries within defined subgroups according to indicators of agricultural and rural development

The previous segment of the analysis leads to the conclusion that the East Central and South-East Europe Countries that are not EU members generally record higher relative values of the analysed indicators compared to those that are EU members. Consequently, it can be concluded that non-EU countries in their overall development rely more on agriculture and rural development than those East Central and South-East Europe Countries that are members of the EU. The question is whether such a conclusion is valid for each country within the analysed subgroups. In order to answer this question, the analysed East Central and South-East Europe Countries are divided into two clusters by respecting and combining the values of all analysed indicators.

Final Cluster Centers shown in Table 4 indicate that the first cluster is a cluster with better performance, i.e., that the first cluster includes countries with greater reliance on agricultural and rural development. On the other hand, the second cluster includes countries with lower performance, if all the analysed indicators of agricultural and rural development are taken into account. The distribution of analysed countries by clusters is shown in Table 5 .

Cluster 1 includes seven countries, of which three are EU members (Bulgaria, Croatia and Poland) and four non-EU countries (Albania, Bosnia and Herzegovina, North Macedonia and Ukraine). Cluster 2 includes ten countries, of which seven are EU members (Cyprus, Czech Republic, Greece, Hungary, Romania, Slovak Republic and Slovenia) and three non-EU countries (Georgia, Montenegro and Serbia). 
Table 4. Final Cluster Centers

\begin{tabular}{|c|c|c|}
\hline \multirow{2}{*}{ Variables } & \multicolumn{2}{|c|}{ Cluster } \\
\hline & 1 & 2 \\
\hline Agricultural land (\% of land area) & 46.98 & 38.47 \\
\hline Arable land ( $\%$ of land area) & 28.40 & 21.56 \\
\hline Forest area ( $\%$ of land area) & 32.53 & 37.35 \\
\hline Agriculture, forestry, and fishing, value added (\% of GDP) & 8.11 & 4.35 \\
\hline Food production index $(2004-2006=100)$ & 135.20 & 90.07 \\
\hline Livestock production index $(2004-2006=100)$ & 104.51 & 84.31 \\
\hline Crop production index $(2004-2006=100)$ & 142.41 & 90.74 \\
\hline Rural population (\% of total population) & 39.49 & 36.89 \\
\hline $\begin{array}{l}\text { Employment in agriculture } \\
\text { (\% of total employment) }\end{array}$ & 16.41 & 12.51 \\
\hline $\begin{array}{l}\text { Employment in agriculture, female } \\
\text { (\% of female employment) }\end{array}$ & 15.86 & 11.54 \\
\hline $\begin{array}{l}\text { Employment in agriculture, male } \\
\text { (\% of male employment) }\end{array}$ & 16.98 & 13.29 \\
\hline
\end{tabular}

Source: Authors' calculation (SPSS Statistics 23)

Table 5. Cluster Membership

\begin{tabular}{|c|c|c|}
\hline Case Number & Cluster & Distance \\
\hline Albania & 1 & 62.189 \\
\hline Bosnia and Herzegovina & 1 & 35.708 \\
\hline Bulgaria & 1 & 34.075 \\
\hline Croatia & 1 & 32.733 \\
\hline Cyprus & 2 & 47.869 \\
\hline Czech Republic & 2 & 36.390 \\
\hline Georgia & 2 & 63.774 \\
\hline Greece & 2 & 21.499 \\
\hline Hungary & 2 & 39.196 \\
\hline North Macedonia & 1 & 26.574 \\
\hline Montenegro & 2 & 60.920 \\
\hline Poland & 1 & 33.081 \\
\hline Romania & 2 & 42.056 \\
\hline Serbia & 2 & 29.514 \\
\hline Slovak Republic & 2 & 37.399 \\
\hline Slovenia & 1 & 33.573 \\
\hline Ukraine & & 73.672 \\
\hline
\end{tabular}

Source: Authors' calculation (SPSS Statistics 23) 
Examination of the interdependence of agricultural and rural development indicators in the East Central and South-East Europe Countries

This segment of the analysis is based on the group (East Central and SouthEast Europe Countries) level data. In order to examine the interdependence of the analysed indicators of agricultural and rural development, Spearman's rank Correlation Coefficients are calculated.

The values of coefficients $(\rho)$ and corresponding levels of significance (pvalues) are shown in Table 6. The scale used in interpreting the values of correlation coefficients is the following: "the values of correlation coefficients which are $\leq 0.35$ are considered to represent low or weak correlation, from 0.36 to 0.67 represent modest or moderate correlation and from 0.68 to 1 represent strong or high correlation, where the values $\geq 0.9$ indicate very high correlation" (Taylor, 1990). The focus in the interpretation is on the coefficients at which the existence of statistical significance is determined.

When it comes to the "Agricultural land (\% of land area)" indicator, high positive statistically significant correlation between this indicator and the "Arable land ( $\%$ of land area)" indicator is recorded $(\rho=0.787)$. In addition, the statistically significant moderate correlation between "Arable land (\% of land area)" indicator and "Forest area (\% of land area)" indicator $(\rho=-0.618)$, as well as "Arable land (\% of land area)" indicator and "Food production index (2004$2006=100)$ " indicator $(\rho=0.485)$ is determined. In the first case, the direction of the link is negative, and in the second positive, which was expected. There is a high statistically significant correlation between "Agriculture, forestry, and fishing, value added (\% of GDP)" indicator and the following indicators: "Employment in agriculture (\% of total employment)" $(\rho=0.746)$, "Employment in agriculture, female (\% of female employment)" $(\rho=0.720)$ and "Employment in agriculture, male $(\%$ of male employment $)$ “ $(\rho=0.727)$. "Food production index $(2004-2006=100)$ " indicator is moderately positively correlated with the "Livestock production index $(2004-2006=100) “(\rho=0.623)$ and highly positively correlated with "Crop production index $(2004-2006=100) “(\rho=$ 0.949).

Very high positive correlation is recorded between: "Employment in agriculture (\% of total employment)" and "Employment in agriculture, female (\% of female employment)" $(\rho=0.993)$, "Employment in agriculture $(\%$ of total employment)" and "Employment in agriculture, male (\% of male employment)" ( $\rho=0.988)$, as well as "Employment in agriculture, female (\% of female employment)" and "Employment in agriculture, male (\% of male employment)" $(\rho=0.978)$. All other correlation coefficients shown in the Table 6 indicate a low to moderate correlation between certain indicators that is not statistically significant. 
Table 6. Correlation matrix

\begin{tabular}{|c|c|c|c|c|c|c|c|c|c|c|c|}
\hline & 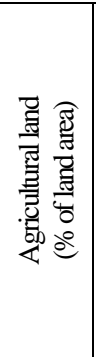 & 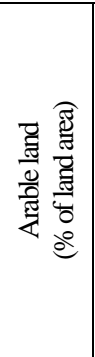 & 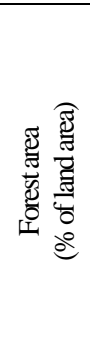 & 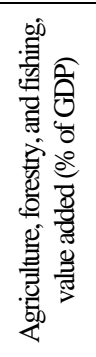 & 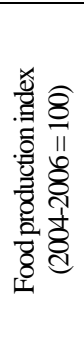 & 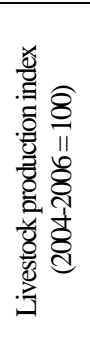 & 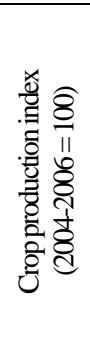 & 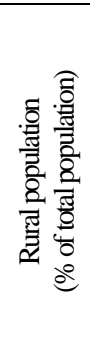 & 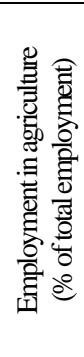 & 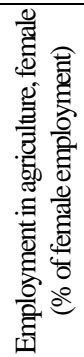 & 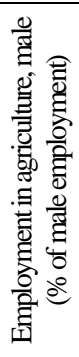 \\
\hline $\begin{array}{c}\text { Agricultural } \\
\text { land } \\
(\% \text { of land area })\end{array}$ & 1.000 & & & & & & & & & & \\
\hline $\begin{array}{c}\text { Arable land } \\
(\% \text { of land area })\end{array}$ & $\begin{array}{c}\mathbf{0 . 7 8 7} \\
(* * *)\end{array}$ & 1.000 & & & & & & & & & \\
\hline $\begin{array}{c}\text { Forest area } \\
(\% \text { of land area })\end{array}$ & $\begin{array}{c}-0.434 \\
(0.082)\end{array}$ & $\begin{array}{c}-\mathbf{- 0 . 6 1 8} \\
(* *)\end{array}$ & 1.000 & & & & & & & & \\
\hline \begin{tabular}{|c|} 
Agriculture, \\
forestry, and \\
fishing, value \\
added \\
(\% of GDP) \\
\end{tabular} & $\begin{array}{c}0.255 \\
(0.323)\end{array}$ & $\begin{array}{c}0.013 \\
(0.959)\end{array}$ & $\begin{array}{l}-0.119 \\
(0.649)\end{array}$ & 1.000 & & & & & & & \\
\hline $\begin{array}{c}\text { Food } \\
\text { production } \\
\text { index }(2004 \\
2006=100)\end{array}$ & $\begin{array}{c}0.451 \\
(0.069)\end{array}$ & $\begin{array}{c}0.485 \\
(*)\end{array}$ & $\begin{array}{l}-0.275 \\
(0.286)\end{array}$ & $\begin{array}{c}0.256 \\
(0.321)\end{array}$ & 1.000 & & & & & & \\
\hline $\begin{array}{c}\begin{array}{c}\text { Livestock } \\
\text { production } \\
\text { index }(2004 \\
2006=100)\end{array} \\
\end{array}$ & $\begin{array}{c}0.225 \\
(0.384)\end{array}$ & $\begin{array}{c}0.145 \\
(0.580)\end{array}$ & $\begin{array}{l}-0.223 \\
(0.390)\end{array}$ & $\begin{array}{c}0.173 \\
(0.507)\end{array}$ & $\begin{array}{c}0.623 \\
(* *)\end{array}$ & 1.000 & & & & & \\
\hline $\begin{array}{c}\text { Crop } \\
\text { production } \\
\text { index }(2004 \\
2006=100)\end{array}$ & $\begin{array}{c}0.395 \\
(0.117)\end{array}$ & $\begin{array}{c}0.466 \\
(0.060)\end{array}$ & $\begin{array}{l}-0.257 \\
(0.319)\end{array}$ & $\begin{array}{c}0.256 \\
(0.321)\end{array}$ & $\begin{array}{c}0.949 \\
(* *)\end{array}$ & $\begin{array}{c}\mathbf{0 . 5 3 7} \\
(*)\end{array}$ & 1.000 & & & & \\
\hline $\begin{array}{c}\text { Rural } \\
\text { population } \\
\text { (\% of total } \\
\text { population) }\end{array}$ & $\begin{array}{c}-0.252 \\
(0.328)\end{array}$ & $\begin{array}{l}-0.201 \\
(0.439)\end{array}$ & $\begin{array}{c}0.380 \\
(0.133)\end{array}$ & $\begin{array}{c}0.056 \\
(0.830)\end{array}$ & $\begin{array}{c}0.059 \\
(0.823)\end{array}$ & $\begin{array}{c}0.213 \\
(0.411)\end{array}$ & $\begin{array}{c}0.049 \\
(0.852)\end{array}$ & 1.000 & & & \\
\hline $\begin{array}{c}\text { Employment in } \\
\text { agriculture (\% } \\
\text { of total } \\
\text { employment) }\end{array}$ & $\begin{array}{c}0.262 \\
(0.309)\end{array}$ & $\begin{array}{l}-0.015 \\
(0.955)\end{array}$ & $\begin{array}{l}-0.096 \\
(0.715)\end{array}$ & $\begin{array}{c}\mathbf{0 . 7 4 6} \\
(* *)\end{array}$ & $\begin{array}{c}0.223 \\
(0.390)\end{array}$ & $\begin{array}{c}0.360 \\
(0.155)\end{array}$ & $\begin{array}{c}0.130 \\
(0.619)\end{array}$ & $\begin{array}{c}0.250 \\
(0.333)\end{array}$ & 1.000 & & \\
\hline \begin{tabular}{|c|} 
Employment in \\
agriculture, \\
female (\% of \\
female \\
employment)
\end{tabular} & $\begin{array}{c}0.262 \\
(0.309)\end{array}$ & $\begin{array}{c}-0.032 \\
(0.903)\end{array}$ & $\begin{array}{l}-0.022 \\
(0.933)\end{array}$ & $\begin{array}{c}0.720 \\
(* *)\end{array}$ & $\begin{array}{c}0.255 \\
(0.323)\end{array}$ & $\begin{array}{c}0.380 \\
(0.133)\end{array}$ & $\begin{array}{c}0.150 \\
(0.567)\end{array}$ & $\begin{array}{c}0.277 \\
(0.282)\end{array}$ & $\begin{array}{c}0.993 \\
(* *)\end{array}$ & 1.000 & \\
\hline $\begin{array}{c}\text { Employment in } \\
\text { agriculture, } \\
\text { male }(\% \text { of } \\
\text { male } \\
\text { employment) } \\
\end{array}$ & $\begin{array}{c}0.284 \\
(0.269)\end{array}$ & $\begin{array}{c}0.042 \\
(0.874)\end{array}$ & $\begin{array}{l}-0.145 \\
(0.580)\end{array}$ & $\begin{array}{c}0.727 \\
(* *)\end{array}$ & $\begin{array}{c}0.299 \\
(0.244)\end{array}$ & $\begin{array}{c}0.373 \\
(0.141)\end{array}$ & $\begin{array}{c}0.213 \\
(0.411)\end{array}$ & $\begin{array}{c}0.267 \\
(0.300)\end{array}$ & $\begin{array}{c}0.988 \\
(* *)\end{array}$ & $\begin{array}{c}0.978 \\
(* *)\end{array}$ & 1.000 \\
\hline
\end{tabular}

** Correlation is significant at the 0.01 level (2-tailed).

* Correlation is significant at the 0.05 level (2-tailed).

Source: Authors' calculation (SPSS Statistics 23) 


\section{CONCLUSIONS}

Indicators of agricultural and rural development in the East Central and South-East European countries were the subject of the analysis in the paper. The heterogeneity of this group of countries enabled their further division into EU and non-EU countries, which is used in certain segments of research in order to provide answers to research questions, i.e., hypotheses. In this regard, the results of descriptive statistics given separately for EU and non-EU countries from the group of the East Central and South-East European countries showed that the maximum values of almost all analysed indicators (except "Forest area (\% of land area)"), as well as the higher mean values of almost all analysed indicators (except "Arable land (\% of land area)"), have been observed in one of the nonEU countries. Based on this, the first initial assumption of the research was confirmed. Namely, East Central and South-East European countries that are not members of the EU record relatively better results (relative values of indicators of agricultural and rural development) compared to a subgroup of EU countries. The importance of agricultural and rural development for the overall development is higher in the non-EU countries of the analysed group. The analysis of variance found that a statistically significant difference between the defined subgroups of countries exists when it comes to "Agriculture, forestry, and fishing, value added (\% of GDP)", "Employment in agriculture (\% of total employment)", "Employment in agriculture, female (\% of female employment)" and "Employment in agriculture, male (\% of male employment)", hence, macroeconomic indicators of agricultural and rural development.

The first segment of the analysis was the basis for examining the homogeneity of countries within defined subgroups. Two groups of countries were singled out by cluster analysis, cluster 1 , as a cluster with better performance according to the analysed indicators and cluster 2 , as a cluster with weaker performance, taking into account the values of all analysed indicators. It was expected that the distribution of countries by clusters would coincide with the previous division into non-EU and EU countries, i.e., that the structure of countries in cluster 1 would correspond to the structure of countries in the subgroup of non-EU countries, and in cluster 2 to the structure of countries in the EU subgroup. However, that did not happen. In this way, the second assumption of the research was rejected. Three non-EU countries (Georgia, Montenegro and Serbia) belong to the second cluster, i.e., the cluster with weaker performance. Also, three EU countries (Bulgaria, Croatia and Poland) belong to cluster 1, a cluster with better performance.

The research assumption tested by correlation analysis was that there is a statistically significant relationship between all analysed indicators of agricultural and rural development in East Central and South-East European countries. As a statistically significant relationship was found between a relatively small number of analysed indicators, it can be concluded that this assumption is not valid for the observed group of countries. 
The main limitation of the research is reflected in the static approach and analysis of the data from one year. The analysis of selected indicators of agricultural and rural development in East Central and South-East European countries in the dynamics of time may be the subject of future research. In this way, it would be possible to more accurately identify countries of good practice, but also to systemize critical indicators by the analysed countries that require improvement in the coming period and greater attention of agricultural and rural development policy makers.

\section{ACKNOWLEDGEMENTS}

The authors declare no conflict of interest.

\section{REFERENCES}

Bryden, J., \& Shucksmith, M. (2000). The Concept of Sustainability in relation to agriculture and rural development in the European Union. Rural and Regional Development in Northern Periphery, Report, 4(00).

Bryden, J., Copus, A., \& Macleod, M. (2001). Rural development. Landsis geie Luxembourg: Proposal on Agri-Environmental Indicators PAIS.

Ciutacu, C., Chivu, L., \& Andrei, J. V. (2015). Similarities and dissimilarities between the EU agricultural and rural development model and Romanian agriculture. Challenges and perspectives. Land Use Policy, 44, 169-176. https://doi.org/10.1016/i.landusepol.2014.08.009

Despotović, A., Joksimović, M., \& Jovanovic, M. (2016). Socio-economic development requirements for agrotourism in Montenegro. Agriculture and Forestry, 62(4), 277286. https://doi.org/10.17707/agricultforest.62.4.28

Despotović, A., Joksimović, M., Svržnjak, K., \& Jovanović, M. (2017). Rural areas sustainability: Agricultural diversification and opportunities for agri-tourism development. Agriculture and Forestry, 63(3), 47-62. https://doi.org/10.17707/agricultforest.63.3.06

Dimitrovski, D., Leković, M., \& Joukes, V. (2019). A bibliometric analysis of Crossref agritourism literature indexed in Web of Science. Menadžment $u$ hotelijerstvu $i$ turizmu - Hotel and Tourism Management, 7(2), 25-37. https://doi.org/10.5937/menhottur1902025d

Erokhin, V., Heijman, W., \& Ivolga, A. (2014). Sustainable rural development in Russia through diversification: The case of the Stavropol Region. Visegrad iournal on bioeconomy and sustainable development, 3(1), 20-25. https://doi.org/10.2478/vjbsd-2014-0004

Filipović, N. (2018). Intangible cultural heritage as a motive for choosing the tourist destination Aranđelovac, Menadžment u hotelijerstvu i turizmu - Hotel and Tourism Management, 6(1), 53-62. https://doi.org/10.5937/menhottur1801053f

Gajić, T., Vujko, A., Cvijanović, D., Penić, M., \& Gagić, S. (2017). The state of agriculture and rural development in Serbia. R-Economy, 3(4), 196-202. https://doi.org/10.15826/recon.2017.3.3.022

Hossain, M., Begum, E., \& Papadopoulou, E. (2015). Factors of rural development driver in Southeastern Bangladesh. American Journal of Rural Development, 3(2), 34-40.

Ilić, I., Krstić, B., \& Jovanović, S. (2017). Environmental performances of agriculture in the European Union countries. Economics of Agriculture, 64(1), 41-55.

Katić, B., Cvijanović, D., \& Pejanović, R. (2011). The agriculture as a real assumption of regional and rural development in Serbia. Rural Areas and Development, 8(3), 77 89.

MAFF (2000). Towards sustainable agriculture: A pilot set of indicators. (available at http://www.adlib.ac.uk/resources/000/015/650/pilotindicators.pdf). 
McRae, T., Smith, C. S., \& Gregorich, L. J. (2000). Environmental sustainability of Canadian agriculture: Report of the agri-environmental indicator project: A summarv. Agriculture and Agri-Food Canada.

Mickovic, B., Mijanovic, D., Spalevic, V., Skataric, G., \& Dudic, B. (2020). Contribution to the analysis of depopulation in rural areas of the Balkans: Case study of the Municipality of Niksic, Montenegro. Sustainability, 12(8), 3328. https://doi.org/10.3390/su12083328

Pierangeli, F., Henke, R., \& Coronas, M. G. (2008). Multifunctional agriculture: An analysis of country specialization and regional differentiation. 12th Congress of the European Association of Agricultural Economists - EAAE 2008, 1-6.

Piorr, H. P. (2003). Environmental policy, agri-environmental indicators and landscape indicators. Agriculture, Ecosystems \& Environment, 98(1-3), 17-33. https://doi.org/10.1016/s0167-8809(03)00069-0

Podovac. M., Đorđević, N.. \& Milićević, S. (2019). Rural tourism in the function of life quality improvement of rural population on Goč mountain. Economics of Agriculture, 66(1), 205-220. https://doi.org/10.5937/ekopoli1901205p

Rischkowsky, B., \& Pilling, D. (2007). The state of the world's animal genetic resources for food and agriculture. Food \& Agriculture Organization.

Saarinen, J. (2007). Contradictions of rural tourism initiatives in rural development contexts: Finnish rural tourism strategy case study. Current Issues in Tourism, 10(1), 96-105. https://doi.org/10.2167/cit287.0

Spalevic, V., Lakicevic, M., Radanovic, D., Billi, P., Barovic, G., Vujacic, D., Sestras, P., \& Khaledi Darvishan, A. (2017a). Ecological-Economic (Eco-Eco) modelling in the river basins of mountainous regions: Impact of land cover changes on sediment yield in the Velicka Rijeka, Montenegro. Notulae Botanicae Horti Agrobotanici ClujNapoca , 45(2), 602-610. https://doi.org/10.15835/nbha45210695

Spalevic, V., Radanovic, D., Skataric, G., Billi. P., Barovic, G., Curovic, M., Sestras, P., \& Khaledi Darvishan, A. (2017b). Ecological-economic (eco-eco) modelling in the mountainous river basins: Impact of land cover changes on soil erosion. Agriculture and Forestry, 63(4), 9-25. https://doi.org/10.17707/agricultforest.63.4.01

Taylor, R. (1990). Interpretation of the correlation coefficient: A basic review. Journal of Diagnostic Medical Sonography, 6(1), 35-39. https://doi.org/10.1177/875647939000600106

Trišić, I. (2019). Opportunities for sustainable tourism development and nature conservation in Special Nature Reserve "Deliblatska peščara." Menadžment u hotelijerstvu $i$ turizmu - Hotel and Tourism Management, 7(1), 83-93. https://doi.org/10.5937/menhottur1901083t

UNGEGN (2020). UNGEGN Divisions (available at https://unstats.un.org/unsd/geoinfo/ungegn/divisions.html).

Wackernagel, M., Linares, A. C., Deumling, D., Schulz, N. B., Sanchez, M. A. V., \& Falfan, I. S. L. (2000). Living Planet Report 2000. WWF Worldwide Network (available at http://www.panda.org/livingplanet).

Wascher, D. M. (2000). Agri-environmental indicators for sustainable agriculture in Europe. European Centre for Nature Conservation.

World Bank (2020). Indicators. Agriculture \& Rural Development (available at https://data.worldbank.org/indicator?tab=all).

Yli-Viikari, A., Risku-Noria, H., Nuutinen, V., Heinonen, E., Hietala-Koivu, R., HuuselaVeistola, E.. ... \& Seppälä, A. (2002). Agri-environmental and rural development indicators: a proposal. Agrifood Research Reports, No. 5. MTT Agrifood Research Finland.

Zekić, S., Kleut. Ž.. \& Matkovski, B. (2017). An analysis of kev indicators of rural development in Serbia: A comparison with EU countries. Economic Annals, 62(214), 107-120. https://doi.org/10.2298/eka1714107z 